\title{
ABOUT DUNG BEETLES (COLEOPTERA: SCARABAEOIDEA) GENITALIA: SOME REMARKS TO A RECENT PAPER
}

Zunino, M. 2014. Acerca de los genitalia en escarabajos (Coleoptera: Scarabaeoidea): algunas observaciones a un artículo reciente. Acta Zoológica Mexicana (n. s.), 30(2): 439-443.

RESUMEN. Se analiza críticamente una publicación extensa sobre los genitalia en diferentes grupos de Coleoptera Scarabaeinae; se subraya la necesidad de revisar las homologías de las diferentes estructuras así como de unificar la nomenclatura en una forma no arbitraria como una precondicionante para su uso en taxonomía y análisis filogenético.

Male, and less frequently female, genitalia characters have often been utilized in beetles taxonomic and phylogenetic research, since as early as the beginning of the 20th century, starting at least from the seminal books by Sharp and Muir (1912), and subsequently by Jeannel (1955), where the genital anatomy of Coleoptera was first systematized (for some historical remarks mostly concerning Scarab beetles see $\mathrm{Zu}-$ nino 2012). The prevailing importance of genitalia not just in alpha taxonomy, but as reliable phylogenetic tracers against external morphological characters underlies a great amount of papers throughout at least fifty years; it was explicitly stressed by Zunino (1983, 1987), Zunino \& Palestrini (1988), and was formally demonstrated by Tarasov \& Solodovnikov (2011) by means of a cladistic analysis of a large sample of Onthophagini. Medina et al. (2013) emphasize the importance of recognizing the homologies within different male genital structures in the frame of Scarabaeinae, and of unifying the relative nomenclature, for several scientific purposes. The authors thank me for "... read[ing] the manuscript and [giving] us important suggestions" (ibid: 474); however, as my former main criticisms to their manuscript (Zunino to Medina and Molano, personal communication, 14/03/2011) were entirely overlooked, even having in mind the ethical principle of the absolute freedom of scientific research, I would like to make the following brief remarks. 
Although the nomenclature of anatomical pieces is not subject to strict priority rules, in the same way as that of taxonomic entities is, it seems quite evident that we need a certain stability, and any change should be explicitly justified, not only due to reasons of fair play, but above all to avoid confusion in the literature. As to this topic, let us examine just a few nomenclature items proposed by Medina et al. (ibid., Tab 2, p. 459).

- "Apical sclerites". These structures were first described, in a group of Onthophagini, by Binaghi et al. (1969) who named them "lamelle accessorie", i. e. accessory lamellae. Their anatomical position is proximal, and can become distal - apical or sub-apical - only during copulation (see figure 1 and 2a). In several phyletic lines one or two pieces may appear more or less strongly differentiated and separated (according to Medina et al., "basal sclerite", "plate sclerite"). Although they were differently named according to distinct authors and systematic groups, it seems important to stress their belonging to the accessory lamellae complex.

- "Medial sclerite". It corresponds to the "lamella copulatrice" (copulatory lame1la) of Binaghi et al. (1969), and is independent of the accessory lamellae and likely not homologous to any of them (Fig. 2b).

- "Raspules" (Fig. 2d). Described by Binaghi et al. (1969), such structures do not correspond to the "cinta espinosa lamelar" quoted by Medina et al. 2013 from Zunino

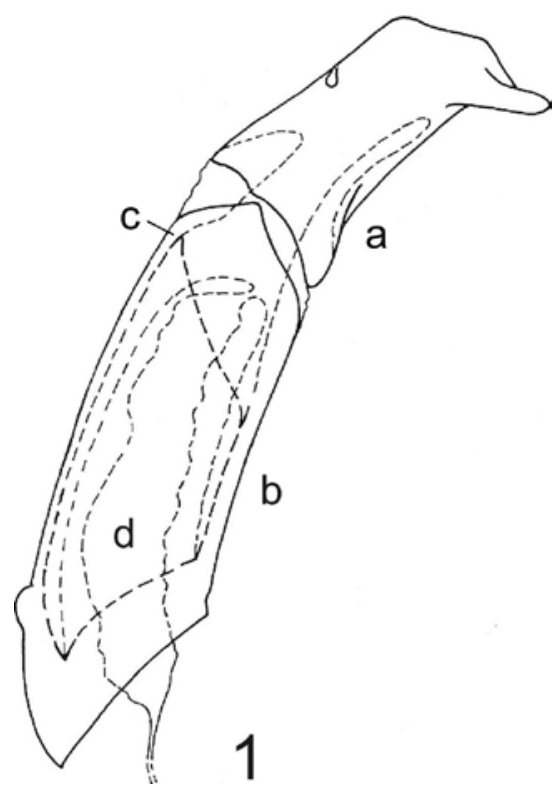

Fig. 1. Male genital structures in a generalized Scarabaeinae beetle (modified from Zunino, 1978). $a$ : paramere; $b$ : phallobase; $c$ : median struts; $d$ : internal sac. 


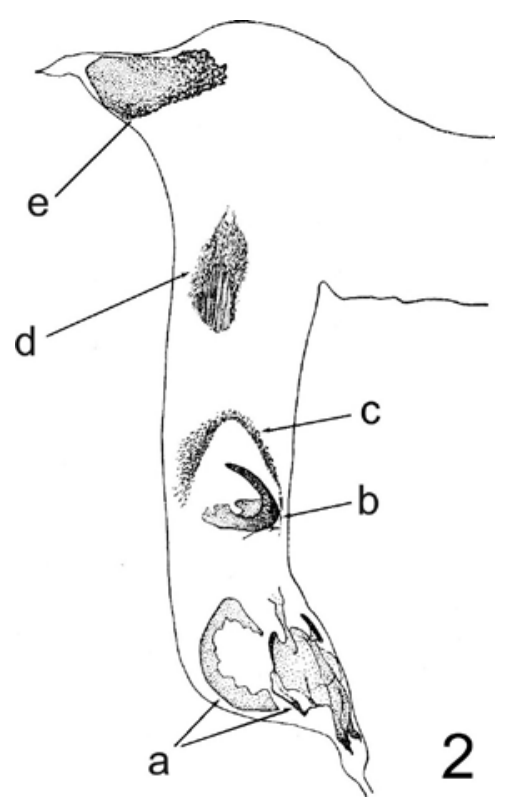

Fig. 2. Sclerotized pieces of the internal sac in Euonthophagus (modified from Zunino, 1972). a: accessory lamellae (left arrow indicates the parietal accessory lamella); $b$ : copulatory lamella; $c$ : lamellar spiny belt; $d$ : raspula; $e$ : specula.

\& Halffter (1988). Once again it is a structure described, as "pacchetto squamigero reniforme", by Binaghi et al.; it was renamed "fascia spinosa lamellare" (lamellar spiny belt: Fig. 2c) by Zunino (1972) in order to stress its intimate connection with the copulatory lamella.

- "Spicule" (Fig. 2e). It is reported as a synonym of "Elongate sclerite" quoting Matthews (1974), who actually used the term in its most undefined sense ("flagellum or spicule"), in order to indicate some sclerotized structures, who really are accessory lamellae. The copulatory spicule was described by Zunino (1972) as "spicola copulatrice" for the genus Euonthophagus Balthasar. Such structure is totally independent of the accessory lamellae complex, and clearly non homologous to any of them (Fig. 2e).

Confusion continues to reign in the nomenclature of the genital anatomy of Scarabaeidae, so that especially its repercussions on the study of real homologies are indeed unlikeable and are not exempt from negative effects on the studies of phylogeny and taxonomy of the group. Although self-quoting can be inelegant, once again I have to refer to my own research, in particular concerning the genus Copris. López Guerrero et al. (2009) studying an American group, described in detail the sclerotized pieces of the internal sac in two species, underlined their taxonomic importance, and named some peculiar structures. An extensive study involving 64 species from 
Africa, Eurasia, and Americas, i.e. all components of the whole distribution area of the genus, as well as representatives of 12 other genera of Scarabaeinae more or less closely related, was published by Marchisio \& Zunino (2012). In this frame, the authors highlighted the lack of any copulatory lamella in the internal sac of Copris, and the presence of two well differentiated accessory lamellae, named (according to the nomenclature created by Binaghi et al.) "parietal accessory lamella" and "(conic) external lamella". By Medina et al., (2013) the first of such structures, as well as the true copulatory lamella of other groups, is considered as belonging to their really heterogeneous "medial sclerite".

It can be assumed, even if only on the basis of the short foregoing considerations, that the whole matter should be revised -as indeed also emphasize Medina et al., (2013). In this context, an extensive collaboration between several researchers is highly desirable, mainly in order to establish true homologies between structures, and hence unequivocally stabilize the nomenclature to be used.

ACKNOWLEDGEMENTS. I am indebted to two anonymous Colleagues, who critically revised an earlier draft of the manuscript, as well as to the - equally anonymous - reviewers of its second version. Roberta Mullini (University of Urbino) deeply revised my English, and Lucrecia Arellano (INECOL) kindly helped me by editing the manuscript.

\section{LITERATURE CITED}

Binaghi, G., Dellacasa, G. \& Poggi, R. 1969. Nuovi caratteri per la determinazione degli Onthophagus del gruppo ovatus (Coleoptera, Scarabaeidae). Memorie della Società Entomologica Italiana, 48: 29-46.

Jeannel, R. 1955. L'édéage. Initiation aux recherches sur la systématique des Coléoptères. Pubications du Muséum National d'Histoire Naturelle de Paris, 16: 1-155.

López Guerrero, I., Zunino, M. \& Halffter, G. 2009. Taxonomic use of genitalic characters in Mexican Copris (Coleoptera: Scarabaeidae: Scarabaeinae): the case of Copris klugi sierrensis Matthews and the C. armatus group. The Coleopterists Bulletin, 63: 203-212.

Marchisio, R. \& Zunino, M. 2012. Il genere Copris Müller. Tassonomia, filogenesi e note di zoogeografia. Word Biodiversity Monographs, 2: 1-174.

Matthews, E. G. 1974. A revision of the Scarabaeinae dung beetles of Australia. II. Tribe Scarabaeini. Australian Journal of Zoology Supplementary Series, 4: 1-211.

Medina, C. A., Molano, F. \& Scholtz, C. H. 2013. Morphology and terminology of dung beetles (Coleoptera: Scarabaeidae: Scarabaeinae) male genitalia. Zootaxa, 3626: 455 - 476.

Sharp, M. A. \& Muir, F. A. G. 1912. The comparative anatomy of the male genital tube in Coleoptera. Transactions of the Entomological Society of London, 1912 (III): 477-642.

Tarasov, S. I. \& Solodovnikov, A. Y. 2011. Phylogenetic analyses reveal reliable morphological markers to classify mega-diversity in Onthophagini dung beetles (Coleoptera: Scarabaeidae: Scarabaeinae) Cladistics, 27: 490-528.

Zunino, M. 1972. Revisione delle specie paleartiche del genere Onthophagus Latr. (Coleoptera Scarabaeoidea). I. Il sottogenere Euonthophagus Balth. Bolletino del Museo di Zoologia dell' Università di Torino, 1972: 1 - 28. 
Zunino, M. 1978. L'armatura genitale negli Onthophagini: tecniche di preparazione e criteri di studio (Coleoptera Scarabaeoidea). L'informatore del giovane entomologo. Supplemento al Bollettino della Società Entomologica Italiana, 90: 21-26.

Zunino, M. 1983. Essai préliminaire sur l'évolution des armures génitales des Scarabaeinae, par rapport à la taxonomie du groupe et à l'évolution du comportement de nidification (Col. Scarabaeidae). Bulletin de la Société entomologique de France, 88: 531-542.

Zunino, M. 1987. La evolución de los aparatos copuladores: comentarios a W. G. Eberhard, "Sexual selection and animal genitalia". Elytron, 1: 105-107.

Zunino, M. 2012. Cuarenta años de anatomía de las piezas genitales en la taxonomía de los escarabajos (Coleoptera: Scarabaeoidea): el estado del arte. Dugesiana, 18: 197-206.

Zunino, M. \& Halffter, G. 1988. Análisis taxonómico, ecológico y biogeográfico de un grupo americano de Onthophagus (Coleoptera: Scarabaeidae). Monografie del Museo Regionale di Scienze Naturali, Torino, 9: 1-211.

Zunino, M. \& Palestrini, C. 1988. L'evoluzione differenziale dei caratteri e il riconoscimento delle specie nei Coleotteri Scarabeidi, pp. 173-176. In: P. Omodeo, P. Burighel \& P. Tongiorgi (Eds.). Il problema biologico della specie. Mucchi, Modena.

\section{MARIo ZUNiNO}

Dept. DiSTeVA, University of Urbino "Carlo Bo", Campus E. Mattei, 61029 Urbino, Italy

<mario.zunino@uniurb.it> 